\title{
Temperature, Irradiance, Photoperiod, and Growth Retardants Influence Greenhouse Production of Angelonia angustifolia Benth. Angel Mist Series
}

\author{
Amanda Miller ${ }^{1}$ and Allan M. Armitage ${ }^{2}$ \\ Department of Horticulture, Plant Sciences Building, University of Georgia, \\ Athens, GA 30602
}

\section{Additional index words. ornamentals, flowering}

\begin{abstract}
The influence of temperature, irradiance, photoperiod and growth retardants on growth and flowering of Angelonia angustifolia Angel Mist series was evaluated. When temperature was increased from 15 to $30^{\circ} \mathrm{C}$, time to visible bud and time to flower decreased in a quadratic manner but total plant height and flower stem dry weight increased linearly. As irradiance increased, time to flower, time to visible bud, and height decreased quadratically. Changes in photoperiod had no effect on growth or flowering, suggesting that $A$. angustifolia is a day-neutral species with regards to height and flowering time. Daminozide, ancymidol, and paclobutrazol resulted in significant reduction of plant height compared with control plants but did not influence flowering time. Chemical names used: K-cyclopropyl-K-(4-methoxyphenyl)-5-pyrimidinemethanol (ancymidol); butanedioic acid mono (2,2-dimethylhydrazide) (daminozide); K-[(4-chlorophenyl)methyl]-

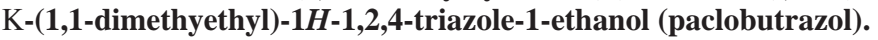

Angelonia angustifolia Benth. (Scrophulariaceae) is native to Mexico and the West Indies. This genus has potential to become a major annual crop in floriculture due to its season-long color and ease of propagation. Plants in this genus are known for their heat tolerance (Bruggeman, 1957) and have recently been incorporated into active breeding programs in a number of major flower-breeding firms. Recently, companies have been successful in breeding resistance to various viruses, in particular the cucumber mosaic virus, which has further revived interest in Angelonia as a landscape plant. These efforts have led to the release of the Angel Mist series, a virus-free series of cultivars available in a range of colors. However, little is known about optimal temperature, irradiance level, photoperiod, and growth-retardant use for production of this species.

With the exception of Antirrhinum majus L. (snapdragon), little research has been conducted on ornamental plants in the Scrophulariaceae family. In general, Antirrhinum is a facultative long-day (LD) plant in which short days retard flowering in most cultivars (Hedley, 1974). Miller (1962) found that optimum temperature for growth of snapdragons decreased as plants matured. Tayama and Miller (1965) also determined that optimal temperature decreased from $21^{\circ} \mathrm{C}$ for 4 week-old plants to $13^{\circ} \mathrm{C}$ when plants were 24 weeks old. The growth retardant uniconizole was effective in reducing height, while gibberellic acid increased height (Holcomb and

\footnotetext{
Received for publication 11 Jan. 2001. Accepted for publication 5 Sept. 2001.

${ }^{1}$ Former Graduate Student.

${ }^{2}$ Professor.
}

Rose, 1990; Rak and Nowak, 1989). Research with Veronica longifolia L., also in Scrophulariaceae, determined that plants were day-neutral (Ball, 1998).

Although little scientific information has been published on Angelonia, Haas (1996), Armitage (1997), and Oschmann (1999) suggested potential for the species as a pot plant, landscape subject, and cut-flower crop, respectively. Unpublished data on $A$. angustifolia (Ball FloraPlant, Elburn, Ill.) was conducted on a broad range of temperatures and photoperiods for growth. The company determined that plants grew well in temperatures $>15^{\circ} \mathrm{C}$, but did not respond to different photoperiods. To confirm this and to extend information to other environmental variables, experiments were conducted to determine the optimal photoperiod, temperature, irradiance, and growth retardants for greenhouse production of $A$. angustifolia Angel Mist series.

\section{Materials and Methods}

Temperature. Twenty-four rooted tip cuttings ( 4 weeks old) on each of five cultivars that make up the Angel Mist series of Angelonia angustifolia were received on 6 Feb. 1999. The cuttings were transplanted into $10-\mathrm{cm}$ pots containing a commercial soilless medium (Fafard 6-M; Fafard Co., Anderson, S.C.) and were pinched to three nodes 1 week after transplanting. After 9 d, eight plants of each cultivar were placed in growth chambers (Conviron 3244; Conviron, Asheville, N.C.) at constant day and night temperatures of $15 \pm$ $2,22 \pm 2$, or $30 \pm 3^{\circ} \mathrm{C}$. All plants received 800 $\pm 50 \mu \mathrm{mol} \cdot \mathrm{m}^{-2} \cdot \mathrm{s}^{-1}$ of light from incandescent and fluorescent lamps as measured with a quantum sensor (LI-188B; LI-COR, Lincoln,
Nebr.). Plants were rotated within each chamber weekly to ensure equal light exposure, at which time the distances between the plants and the lights were adjusted to maintain similar light levels. Plants were illuminated for 16 $\mathrm{h}$ because of preliminary work (Armitage et al., 2000; Ball FloraPlant, unpublished data) that showed no detrimental effect of that photoperiod. Pots were irrigated with constant liquid feed at $200 \mathrm{mg} \cdot \mathrm{L}^{-1} \mathrm{~N}$ provided by $15-0-15$ fertilizer (Peter's Dark Weather Feed; Scotts Co., Milpitas, Calif.) as needed. The pots were leached on every fifth irrigation to prevent soluble salt accumulation. Data were taken on days to visible bud (bud $>1 \mathrm{~mm}$ ), days to flower (two flowers open on the raceme), total height at flowering (height from soil to top of plant), and dry weight of the first flower stem. The flower stem was harvested for dry-weight measurement when about half the flowers on the raceme reached anthesis. The statistical design was completely randomized with eight single-plant replications.

Irradiance. Thirty cuttings of each cultivar were transplanted as previously described. The plants were placed in a glass greenhouse on 15 Feb. 1999 controlled by a Q-COM environmental control system (Q-COMCorp., Irvine, Calif.). Temperature set points were 20 ${ }^{\circ} \mathrm{C}$ day and night temperatures; however, actual temperatures ranged from $20 \pm 5{ }^{\circ} \mathrm{C}$ day/19 $\pm 3{ }^{\circ} \mathrm{C}$ night. Ten cuttings of each cultivar were placed in natural day (ND); ND $+900 \pm 40 \mu \mathrm{mol} \cdot \mathrm{m}^{-2} \cdot \mathrm{s}^{-1}$; or ND +1200 \pm 50 $\mu \mathrm{mol} \cdot \mathrm{m}^{-2} \cdot \mathrm{s}^{-1}$. ND photoperiod was $10 \mathrm{~h} 56$ min on the first day of the experiment and 13 h 6 min on the last day of the experiment. Two high-intensity discharge (HID) lights (400-W metal halide) were used in each supplemental treatment. Light intensity was controlled by the distance between the lamps and the apices of the plants. Light intensity was measured using a quantum sensor (LI-188B; LI-COR) at night and lamps were adjusted every week. Lights were on $24 \mathrm{~h}$ each day. The average daily irradiance $(P P F)$ for the duration of the study (weeks 5-15) was obtained from the Georgia Automated Environmental Monitoring Network at Watkinsville, $\approx 16 \mathrm{~km}$ from the Georgia campus (Fig. 1). Irrigation and data collection were as described in the temperature experiments. The statistical design was completely randomized, with 10 single-plant replications.

Photoperiod. Ninety tip cuttings of each cultivar were received on 10 Dec. 1999 and transplanted as previously described. The plants were pinched to two nodes on $20 \mathrm{Dec}$. 1999 and again on 14 Jan. 2000 to ensure no reproductive tissue was present. Ten plants of each cultivar were placed into nine treatments on 18 Jan. 2000. They were continuous ND, continuous short day (SD), and continuous long day (LD) with night break. Remaining treatments were 2 weeks SD, then LD; 4 weeks SD, then LD; 6 weeks SD, then LD; 2 weeks LD, then SD; 4 weeks LD, then SD; or 6 weeks LD, then SD. All plants were covered with blackcloth each day from 1700 to 0800 hr. Long-day treatments were provided by night interruption by $40-\mathrm{W}$ incandescent bulbs 


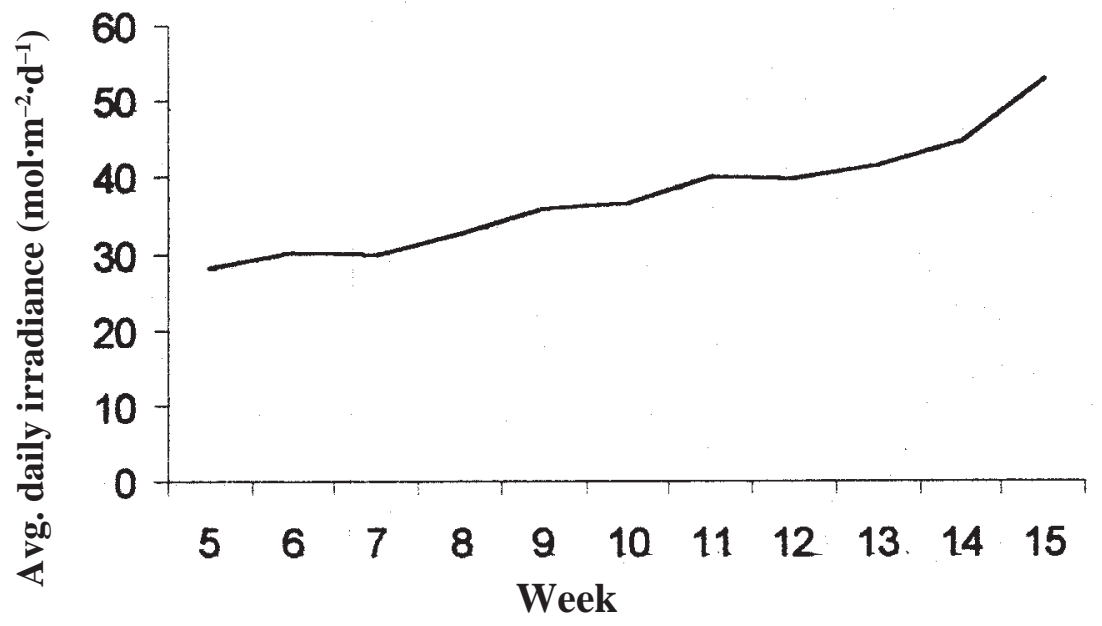

Fig. 1. Irradiance levels for Athens, Ga., weeks 5 to 15, 1999. Data obtained from the Georgia Automated Environmental Monitoring Network at Watkinsville, $\approx 16 \mathrm{~km}$ from the Georgia campus.

providing $\approx \mu \mathrm{mol} \cdot \mathrm{m}^{-2} \cdot \mathrm{s}^{-1}$, from 2200 until 0200 $\mathrm{hr}$, also under the cloth. Night temperatures under the cloth under LD and SD conditions were $20 \pm 5$ and $19 \pm 3{ }^{\circ} \mathrm{C}$, respectively. Day temperatures in the greenhouse were $20 \pm 5$ ${ }^{\circ} \mathrm{C}$. Irrigation and data collection were as described in the temperature experiments. The statistical design was completely randomized, with 10 single-plant replications.

Growth Retardants. Cuttings of all cultivars were received and transplanted into 10cm pots in a glass greenhouse on 15 Dec. 1999. The cuttings were transplanted in a commercial soilless medium (Fafard 6-M) and were pinched to two nodes 1 week after transplanting, similar to the previous experiment. Ten plants of each cultivar received one of the following treatments: ancymidol at 50 or 100 $\mathrm{mg} \cdot \mathrm{L}^{-1}$; paclobutrazol at 50 or $100 \mathrm{mg} \cdot \mathrm{L}^{-1}$; daminozide at 2500 or $5000 \mathrm{mg} \cdot \mathrm{L}^{-1}$; or control. On 5 Jan. $2000, \approx 10 \mathrm{~mL}$ of ancymidol and daminozide were sprayed on each plant, resulting in some spray runoff. About $8 \mathrm{~mL} /$ plant of paclobutrazol was applied in order to minimize runoff. Night/day temperatures, fertilization, irrigation, and data collection were as previously described. The statistical design was completely randomized, with 10 singleplant replications.

Statistical analysis. Data were tested by analysis of variance using the SAS General Linear Model (SAS Institute, Cary, N.C.), and means separated with Duncan's multiple range test, or trend analysis where appropriate.

\section{Results and Discussion}

All cultivars responded similarly to all experiments; therefore, only the data from 'Angel Mist Pink' are presented.

Temperature. Increasing the temperature from 15 to $22{ }^{\circ} \mathrm{C}$ decreased time to visible bud and flowering; however, no additional decreases occurred when the temperature was raised above $22{ }^{\circ} \mathrm{C}$, resulting in a quadratic response to temperature (Table 1 ). Total height of the flowering plant increased linearly as temperature rose. Shoot dry weight also increased in a linear manner as temperature increased. The results show that increasing the temperature significantly influences flowering and growth of Angelonia. This response is similar to that of other tropical species, such as Hamelia patens Jacq., which flowered faster at 25 or $30^{\circ} \mathrm{C}$ than at $20^{\circ} \mathrm{C}$ (Armitage, 1995) and Aseschynanthus Jack 'Koral', which also flowered faster as temperatures increased (Whitton and Healy, 1991). In contrast, although snapdragons are closely related, they are a cool-tolerant species and show little flower delay when soil temperatures decreased fluorescent lamps for $16 \mathrm{~h}$ each day.

${ }^{\mathrm{z}} \mathrm{ND}=$ Natural day. temperatures of $20 \pm 5^{\circ} \mathrm{C}$ day/ $19 \pm 3{ }^{\circ} \mathrm{C}$ night.

${ }^{2}$ Means separated by Duncan's multiple range test, $P \leq 0.05$. from 24 to $20{ }^{\circ} \mathrm{C}$ (Seeley, 1965). Visually, plants in the $22{ }^{\circ} \mathrm{C}$ chamber were of higher quality than plants in the other chambers. The foliage was obviously greener, the internodes were shorter than those in the $30^{\circ} \mathrm{C}$ chamber, and the stems were obviously stouter. Plants in the $15^{\circ} \mathrm{C}$ chamber were shorter than plants in other temperatures (Table 1) but the foliage exhibited chlorosis throughout, with stunted leaves and some marginal necrosis. Plants in the $30^{\circ} \mathrm{C}$ chamber were taller than plants in the other chambers, and the stems were thin and brittle, and easily broken.

In general, the flowering time and flower stem dry weight were negatively affected by the $15^{\circ} \mathrm{C}$ treatment. Plants were stunted, perhaps from the inability to absorb nutrients at cooler temperatures and overall slower biological activity. The plants grew more slowly at $15^{\circ} \mathrm{C}$ than at other temperatures, and were smaller and weighed less at anthesis. Based on the data presented, an optimum day/night temperature of $\approx 22^{\circ} \mathrm{C}$ is suggested.

Irradiance. As irradiance levels increased, days to visible bud and days to flower decreased. The greatest decrease in time for both occurred between ND and ND +900 $\mu \mathrm{mol} \cdot \mathrm{m}^{-2} \cdot \mathrm{s}^{-1}$. A further increase in intensity to $\mathrm{ND}+1200 \mu \mathrm{mol} \cdot \mathrm{m}^{-2} \cdot \mathrm{s}^{-1}$ resulted in less response, thus a significant quadratic trend (Table 2 ). Total height of the plant also showed a quadratic decrease at higher irradiance intensities, with the highest light level resulting in the shortest plants. Dry weight of the flower

Table 1. Influence of temperature on growth and flowering of Angelonia angustifolia 'Angel Mist Pink'. Plants were grown in growth chambers and illuminated with $800 \pm 50 \mu \mathrm{mol} \cdot \mathrm{m}^{-2} \cdot \mathrm{s}^{-1}$ of light from incandescent and

\begin{tabular}{lcccc}
\hline & \multicolumn{3}{c}{ Chamber temp } & \\
\cline { 2 - 4 } & $15^{\circ} \mathrm{C}$ & $22{ }^{\circ} \mathrm{C}$ & $30^{\circ} \mathrm{C}$ & Significance \\
\hline Days to visible bud & 54 & 42 & 44 & $\mathrm{~L}, \mathrm{Q}^{\mathrm{z}}$ \\
Days to flower & 58 & 47 & 50 & $\mathrm{~L}, \mathrm{Q}$ \\
Total ht (cm) & 31.4 & 51.5 & 68.2 & $\mathrm{~L}$ \\
Flower shoot dry wt (g) & 4.6 & 8.1 & 9.3 & $\mathrm{~L}$ \\
\hline
\end{tabular}

${ }^{\mathrm{z}}$ Linear $(\mathrm{L})$ or quadratic $(\mathrm{Q})$ response at $P \leq 0.05$.

Table 2. Influence of irradiance on growth and flowering of Angelonia angustifolia 'Angel Mist Pink'. Temperatures were $20 \pm 5^{\circ} \mathrm{C}$ day $/ 19 \pm 3^{\circ} \mathrm{C}$ night.

\begin{tabular}{lcccc}
\hline & \multicolumn{3}{c}{ Irradiance treatment } & \\
\cline { 2 - 4 } & $\mathrm{ND}^{\mathrm{z}}$ & $\mathrm{ND}+900^{\mathrm{y}}$ & $\mathrm{ND}+1200^{\mathrm{x}}$ & Significance \\
\hline Days to visible bud & 46 & 39 & 35 & $\mathrm{~L}, \mathrm{Q}$ \\
Days to flower & 57 & 49 & 45 & $\mathrm{~L}, \mathrm{Q}$ \\
Total height $(\mathrm{cm})$ & 32.1 & 34.0 & 29.0 & $\mathrm{~L}, \mathrm{Q}$ \\
Flower shoot dry weight $(\mathrm{g})$ & 7.8 & 7.4 & 6.9 & $\mathrm{NS}$ \\
\hline
\end{tabular}

${ }^{\mathrm{y}} \mathrm{Natural}$ day $+900 \mu \mathrm{mol} \cdot \mathrm{m}^{-2} \cdot \mathrm{s}^{-1}$ photon irradiance level.

${ }^{\mathrm{x}}$ Natural day $+1200 \mu \mathrm{mol} \cdot \mathrm{m}^{-2} \cdot \mathrm{s}^{-1}$ photon irradiance level.

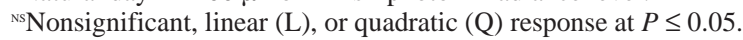

Table 3. Influence of growth retardants on growth and flowering of Angelonia 'Angel Pink Mist', with

\begin{tabular}{|c|c|c|c|c|c|c|c|}
\hline \multirow[b]{3}{*}{ Criterion } & \multirow[b]{3}{*}{ Control } & \multicolumn{6}{|c|}{ Chemical applied $\left(\mathrm{mg} \cdot \mathrm{L}^{-1}\right)$} \\
\hline & & \multicolumn{2}{|c|}{ Ancymidol } & \multicolumn{2}{|c|}{ Paclobutrazol } & \multicolumn{2}{|c|}{ Daminozide } \\
\hline & & 50 & 100 & 50 & 100 & 2500 & 5000 \\
\hline Days to visible bud & $46 \mathrm{bc}$ & $44 c^{z}$ & $44 \mathrm{c}$ & $46 \mathrm{bc}$ & $45 \mathrm{c}$ & $48 \mathrm{ab}$ & $50 \mathrm{a}$ \\
\hline Days to flower & $57 \mathrm{a}$ & $54 \mathrm{~b}$ & $55 \mathrm{ab}$ & $57 \mathrm{a}$ & $57 \mathrm{a}$ & $56 \mathrm{ab}$ & $57 \mathrm{a}$ \\
\hline Total ht $(\mathrm{cm})$ & $47.5 \mathrm{a}$ & $35.7 \mathrm{~b}$ & $33.3 \mathrm{bc}$ & $37.0 \mathrm{~b}$ & $34.7 \mathrm{~b}$ & $32.6 \mathrm{bc}$ & $30.1 \mathrm{c}$ \\
\hline Flower shoot dry wt (g) & $7.7 \mathrm{~b}$ & $8.5 \mathrm{~b}$ & $8.6 \mathrm{~b}$ & $8.3 \mathrm{~b}$ & $9.8 \mathrm{a}$ & $6.5 \mathrm{c}$ & $5.4 \mathrm{~d}$ \\
\hline
\end{tabular}


stem was unaffected by irradiance. The reduction in days to flower and days to visible bud has been noted in many crops, including snapdragons (Stefanis and Langhans, 1982) and Gypsophila paniculata Per. (Hicklenton et al., 1993). Crop production time of Angelonia could be shortened by almost 2 weeks with supplemental lighting.

Photoperiod. The application of SD or LD affected no parameters measured (data not shown), nor did any significant differences occur in the remaining six treatments ( 2 weeks $\mathrm{SD}$, then LD; 4 weeks SD, then LD; 6 weeks $\mathrm{SD}$, then LD; 2 weeks LD, then SD; 4 weeks $\mathrm{LD}$, then $\mathrm{SD}$; or 6 weeks LD, then SD) (data not shown). These results are similar to those obtained for Veronica longifolia (Ball, 1998), a species in the same taxonomic family. Since the days to visible bud and days to flower were unaffected by photoperiod, plants could be produced without regard to daylength and season across the country. No differences in height and flowering time due to photoperiod were observed in any cultivars in the series, suggesting all cultivars would respond similarly in a common greenhouse range.

Growth retardants. Compared to the control, only daminozide at $5000 \mathrm{mg} \cdot \mathrm{L}^{-1}$ delayed days to visible flower bud (Table 3). Except for plants treated with $50 \mathrm{mg} \cdot \mathrm{L}^{-1}$ of ancymidol, anthesis was not delayed by any plant growth retardants. Total height was reduced by all growth retardants. The greatest reduction in height resulted from the application of daminozide at $5000 \mathrm{mg} \cdot \mathrm{L}^{-1}$; however, both concentrations of daminozide decreased flower shoot dry weight (Table 3).
The primary function of a growth retardant is to reduce the height of the plant, and make it more manageable in a container. However, loss of plant volume, as reflected by dryweight measurement, is not a positive outcome, regardless of height control. All growth retardants tested reduce plant height; however, the reduction in stem dry weight with daminozide may not be acceptable. Both ancymidol and paclobutrazol resulted in significant height reduction without increasing flowering time or resulting in phytotoxicity.

With regard to crop production, the data suggest that Angelonia Angel Mist series has potential as a bedding or potted flower crop. The lack of photoperiod response suggests that plants can be produced in all seasons, throughout the country. Flowering times from rooted pinched cuttings were as early as $45 \mathrm{~d}$ with supplemental light to $57 \mathrm{~d}$ with natural light in 20 to $22{ }^{\circ} \mathrm{C}$ greenhouses, a crop time that will not deter growers from producing this crop. In areas with low winter light, supplemental irradiance in winter months can hasten growth and flowering and can be recommended if economically feasible. All cultivars responded similarly to 'Angel Mist Pink' to temperature, irradiance, photoperiod, and growth retardants, making the entire series amenable to greenhouse scheduling.

\section{Literature Cited}

Armitage, A.M. 1995. Photoperiod, irradiance, and temperature flowering of Hamelia patens (Texas Firebush). HortScience 30:255-256.

Armitage, A.M. 1997. Specialty annuals: Angelonia . Greenhouse Grower 10:79-80.
Armitage, A.M., A.M. Miller, and J.M. Garner. 2000. The influence of photoperiod and temperature on growth and flowering of Angelonia angustifolia Benth: A preliminary report. Acta Hort. 541:167-170.

Ball, V. 1998. Ball redbook. Ball Publ., Batavia, Ill. Bruggeman, L. 1957. Tropical plants and their cultivation. Crowell, New York.

Haas, H.P. 1996. Summer pot culture widens plant range. TASPO Gartenbaumagazin 5:22-24.

Hedley, C.L. 1974. Response to light intensity and day-length of two contrasting flower varieties of Antirrhinum majus L. J. Hort. Soc. 49:105-112.

Hicklenton, P.R., S.M. Newman, and L.J. Davies. 1993. Night temperature, photosynthetic, photon flux, and long days affect Gypsophila paniculata flowering. HortScience 28:888-890.

Holcomb, E.J. and M.A. Rose. 1990. Height control of selected bedding plants with uniconizole. Acta Hort. 272:279-284.

Miller, R.G. 1962. Variations in optimal temperature of greenhouse snapdragons depending on plant size. Proc. Amer. Soc. Hort. Sci. 81:535-543.

Oschmann, C. 1999. Newcomers in cut flowers range. TASPO Gartenbaumagazin 8(2):26-30.

Rak, J. and J. Nowak. 1989. The effect of gibberellic acid on growth and flowering of snapdragon cuttings. Acta Hort. 251:67-69.

Seeley, J.G. 1965. Soil temperature and the growth of greenhouse snapdragons. Proc. Amer. Soc. Hort. Sci. 86:693-694.

Stefanis, J.P. and R.W.Langhans. 1982. Snapdragon production with supplemental irradiation from high pressure sodium lamps. HortScience 17:601-603.

Tayama, H.K. and R.O. Miller. 1965. Relationship of plant age and net assimilation rate to optimum growing temperature of the snapdragon. Proc. Amer. Soc. Hort. Sci. 86:672-680.

Whitton, B. and W. Healy. 1991. Flowering of Aeschynanthus 'Koral'. HortScience 26:858-859. 